\title{
The Impact of Corruption on Chinese OFDI-Based on the Binary Marginal Perspective
}

\author{
Yongpei Wu \\ Jinan University, Guangzhou, China \\ Email:wuy0n9pei@163.com
}

How to cite this paper: Wu, Y.P. (2019) The Impact of Corruption on Chinese OFDI-Based on the Binary Marginal Perspective. Modern Economy, 10, 1671-1683. https://doi.org/10.4236/me.2019.107109

Received: May 28, 2019

Accepted: July 9, 2019

Published: July 12, 2019

Copyright (๑) 2019 by author(s) and Scientific Research Publishing Inc. This work is licensed under the Creative Commons Attribution International License (CC BY 4.0).

http://creativecommons.org/licenses/by/4.0/

\begin{abstract}
This paper uses the China Global Investment Tracker database to map the investment panels of 31 countries along the "Belt and Road" in China, using the system GMM (generalised method of moments) estimation method to study the impact of host country corruption on Chinese OFDI (outward foreign direct investment). The conclusion is that the level of corruption in the host country and the Chinese OFDI total scale show a non-linear " $U$ " relationship. From the perspective of intensive margin, the relationship between host country corruption and the average amount foreign investment from Chinese enterprises is not significant. From the perspective of extensive margin, corruption and the number of enterprises setting up factories in the host country also show U-shaped relationship, but the relationship with the number of investment industries is not significant.
\end{abstract}

\section{Keywords \\ OFDI, Corruption, GMM, Binary Marginal}

\section{Introduction}

In recent years, the world economy has been weak and the growth rate of developed economies has dropped significantly. International trade has remained sluggish and some uncertainties such as Brexit have triggered a huge shock in the international financial market. Therefore, it's still rugged for countries around the world to develop and expand their scale of OFDI. The Chinese government has actively promoted the "One Belt and One Road" initiative in 2013 and steadily carried out international capacity cooperation. The "going out" work system has been continuously improved, so Chinese enterprises take the initiative to 
accelerate integration into the process of economic globalization. According to the 2016 China Foreign Direct Investment Statistics Bulletin, Chinese OFDI net in 2016 increased by $34.7 \%$ year-on-year, setting a record high of 196.15 billion (US dollar) and ranking second in the world.

China's OFDI not only flows into developed countries, but also developing countries. $80 \%$ of OFDI flows into developing countries and regions in Asia, Africa and Latin America. Cheap labor, abundant natural resource endowments and broad market prospects are the main reasons for attracting OFDI inflows. However, developing countries often have an immature institutional environment and corruption problems naturally arise. Corruption in the host country may bring higher entry costs to multinational companies so that it affects the way in which multinational companies enter or the location of multinational companies. Since 2013, China has proposed the construction of the "Belt and Road", which is to encourage Chinese enterprises to take the initiative to "go out". Because most of the countries along the "Belt and Road" are developing countries, there are a lot of problems about institutions and corruption. Therefore, this paper has important practical significance in studying the relationship between corruption and OFDI in China. I hope this paper can provide some help for Chinese enterprise OFDI.

\section{Literature Review}

At present, the academic community does not form a consistent conclusion on the relationship between the level of corruption in the host country and OFDI. There are mainly the following viewpoints. The traditional view is that corruption in the host country will have a "frictional effect" and curb the inflow of transnational OFDI, because the occurrence of corruption in the host country will increase the uncertainty of the investment environment, reduce the predictability of investment activities, and increase investors sunken cost [1]. Blonigen [2] believes that the mechanism of host country system affecting FDI is mainly reflected in the following aspects. First, the bad institutional environment increases the risk of deprivation of investor assets, thereby reducing the likelihood of investment. Defects in the protection of property rights system will hinder investment. Second, the institutional defects in the regulation of market operations will increase investment costs. Problems such as rent-seeking and corruption increase investment costs, so companies will reduce investment activities. Third, institutional deficiencies often result in poor quality of public goods (such as the judicial system, government efficiency, and regulation) provided by the government, thus affecting the expected return on investment. The findings of Demirbag et al. [3], Driffield et al. [4], and Duanmu [5] are similar. They believe that corruption will lead investors to face more uncertainty and need to pay additional operating costs for learning and adapting to the culture, customs, values, business rules. It's the reason that corruption inhibits foreign direct investment by companies. Das and Parry [6] used data from direct investment in 74 developing coun- 
tries in the United States from 2000 to 2008. The empirical results also show that host country corruption will inhibit US direct investment in developing countries.

Another view in the academic world is contrary to the above point of view. It is believed that the corruption actually has a "lubricating effect". The corruption is conducive to the entry of OFDI and attracts more OFDI. The host country's relatively inferior institutional environment will induce host country government officials' initiative to create rents. The distorted incentives for investors to engage in corrupt behavior will be further strengthened, so that some multinational companies with higher ownership advantages also choose corruption as an alternative source of incentives. Egger and Winner [7] used data from 73 countries that absorbed cross-border direct investment in 1995-1999 and found that corruption can help investors bypass the host country's unreasonable government regulation of foreign investment in a relatively inferior institutional environment. Corruption facilitates transnational inflow of direct investment. Cazurra [8] based on data from 183 home countries' direct investments in 106 host countries, also found that host country corruption has a positive effect on cross-border direct investment. In an empirical study on the level of China's OFDI and host country corruption, Buckley et al. [9] used China's OFDI data from 49 countries in 1984-2001 to study the location distribution characteristics of China's OFDI. It also founded that corruption has a positive effect on Chinese OFDI. Kolstad and Wiig [10] used the 2003-2006 China cross-sectional data on OFDI in 104 countries and found that the quality of the host country institution is negatively correlated with China's OFDI. They believe that China's OFDI preferred the country with imperfect institutions and further supported the views of Buckley. Chinese OFDI entering non-OECD countries has significant resource seeking motivation and likes to invest in countries and regions with imperfect institution systems. Cheung et al. [11] considered the impact of host country corruption when examining China's OFDI determinants for African countries and found that host country corruption has a positive proportional relationship with China's OFDI inflows. Jiang Guanhong and Jiang Dianchun [12] analyzed China's investment in developing countries and examined the impact of the quality of the host country system including corruption on Chinese OFDI. They found that Chinese OFDI favored host countries with worse corruption control. Fung and Garcia [13] compared the factors affecting FDI between China and India and founded that the higher level of corruption would attract more OFDI in China.

The third view is that there is not a linear relationship between host country corruption and OFDI, but a non-linear relationship. Straub [14] made a game Analysis between multinational corporations and host Countries. He founded that corruption makes transnational investors not inclined to enter the host country by direct investment but by choosing bank loans. When the level of corruption rises to a higher level, transnational direct investors tend to invest directly in the host country. Méon and Weill [15] used empirical data from 54 countries to find that in countries with high institutional quality, corruption is detrimental to production efficiency, while in countries with low institutional 
quality, corruption is beneficial to production efficiency. Craigwell and Wright [16] used developing country data as a sample and found that host country corruption has a certain non-linear effect on cross-border direct investment. Brada et al. [17] used data from direct investment by host countries in transition countries and found that the nonlinear relationship between host country corruption and transnational direct investment still exists. Hu Bing, Deng Fuhua, and Zhang Ming [18] believe that under certain system constraints, there is a "threshold effect" on the influence of host country corruption on Chinese OFDI. When the level of corruption in the host country is low, the "frictional effect" of corruption will have a negative impact on Chinese OFDI. However, when the host country's corruption exceeds a certain threshold, Corruption can be used as a sub-optimal choice to produce a certain degree of "lubrication effect" on China's OFDI, which will have a certain positive impact on China's OFDI.

The above is the academic research on the relationship between host country corruption and OFDI. Almost all of them are based on the perspective of OFDI's one-dimensional scale, that is, empirical research is conducted on the explanatory variables of investment flows or investment stocks and there are disadvantages in empirical methods and models. Compared to previous research, there are two innovations in this article. The first is the research perspective. This paper studies the impact of corruption on Chinese OFDI from the perspective of intensive margin and extensive margin. The binary marginal perspective is more helpful in clarifying the impact of corruption on the structural characteristics of OFDI. The second is the empirical method. This paper uses the method of system GMM to empirical research. Most of the previous empirical studies used gravity models or panel static models, without considering OFDI continuity and dynamic effects. This paper uses the GMM method to overcome these disadvantages and make the estimation results more credible.

\section{Data and Empirical Models}

The basic empirical regression model is as follows:

$$
\begin{gathered}
\operatorname{lnfdi}_{i t}=\beta_{0}+\beta_{1} \operatorname{lnfdi}_{i, t-1}+\beta_{2} \operatorname{cor}_{i t}+\sum \beta_{n} X_{n t}+\gamma_{i}+\varepsilon_{i t} \\
\operatorname{lnifdi}_{i t}=\beta_{0}+\beta_{1} \text { lnifdi }_{i, t-1}+\beta_{2} \operatorname{cor}_{i t}+\sum \beta_{n} X_{n t}+\gamma_{i}+\varepsilon_{i t} \\
\operatorname{exfdi}_{i t}=\beta_{0}+\beta_{1} \operatorname{exfdi}_{i, t-1}+\beta_{2} \operatorname{cor}_{i t}+\sum \beta_{n} X_{n t}+\gamma_{i}+\varepsilon_{i t} \\
\operatorname{exfdi}_{i t}=\beta_{0}+\beta_{1} \operatorname{exfdi}_{i, t-1}+\beta_{2} \operatorname{cor}_{i t}+\sum \beta_{n} X_{n t}+\gamma_{i}+\varepsilon_{i t}
\end{gathered}
$$

The estimation method used in this paper is the dynamic panel system GMM. The GMM model can effectively reflect the dynamic effects of OFDI and consider the continuity of OFDI. It can better solve the endogenous and make the estimated results less biased and more robust. We first estimate the above four regression models, and then introduce the square of the corruption $\mathrm{cor}^{2}$ to estimate whether the host country corruption level has a nonlinear relationship with Chinese OFDI.

The OFDI data studied in this paper is from China Global Investment Tracker, 
which is established by American Enterprise Research Institute and American Heritage Foundation. The database contains the names of Chinese investment enterprises, the amount of FDI, the proportion of investment scale, foreign cooperative enterprises, foreign investment first-level industries, foreign investment secondary industries, host countries and their regions. Due to the lack of Chinese OFDI statistics along the "Belt and Road" countries, OFDI has not been carried out in some years and the empirical results may be biased. Therefore, this paper use the panel data of the 31 countries along the "Belt and Road" for 2010-2017 for empirical research. This paper refers to the practice of Yang [19]. We define the intensive margin of investment as the average investment amount of OFDI country-industry pairs in a year, reflecting the scale of OFDI of a country's enterprises. We define the extensive margin of investment as the number of investment enterprises and investment industries in the host country, reflecting Chinese diversification of investment in the host country. $\operatorname{lnfdi_{it}}$, lnifdi $i_{i t}$, exfdi $1_{i t}$ and exfdi $2_{i t}$ represent respectively the logarithm of Chinese OFDI total scale in year $t$ and in country $i$, the logarithm of average OFDI in year $t$ and in country $i$, the number of investment enterprises and the number of investment industries in year $t$ and in country $i$. The average OFDI is equal to the total investment of all companies in the $t$ year of the country $i$ divided by the number of companies.

The core dependent variable corruption level is adopted by Transparency International's annual Corruption Perception Index (CPI). The CPI index is a composite index of the results of surveys conducted by institutions with high credibility in the world. The score is 10 points and the lowest score is 0 points. Higher scores mean less corruption. The index is widely used by academics and governments. In order to facilitate the interpretation of regression results, we reversed the value of CPI. Defining $c o r_{i t}=10-c p i_{i t}$. cor $r_{i t}$ indicates the corruption of country $i$ in year $t$.

$\operatorname{lnfdi} i_{i, t-1}, \operatorname{lnifdi} i_{i, t-1}, \operatorname{exfdi}_{i, t-1}$ and exfdi $2_{i, t-1}$ are the lag term of independent variable in the regression model, which are used to reflect the dynamics of the regression model and to test the aggregation effect of OFDI.

$X_{n t}$ are control variables, including the market size of the host country Inmar, the labor cost of the host country lnlab, the economic development potential of the host country $g g d p$, the trade openness of the host country open, the natural resource endowment of the host countryres. Allthe variables related to GDP use the 2010 constant dollar for GDP conversion. Control variables are collected in the World Bank database. All variable indicators, constructions, and sources are shown in the Table 1.

\subsection{Empirical Results and Analysis}

\section{Statistical Description}

Table 2 is a statistical description of the measurement model variables in this paper. 
Table 1. Variables indicators, constructions, and sources.

\begin{tabular}{cccc}
\hline variable & indicators & construction & source \\
\hline Infdi & OFDI total scale & $\ln ($ ofdi) & \\
Inifdi & intensive margin & $\ln$ (average ofdi) & $\begin{array}{c}\text { China Global } \\
\text { Investment } \\
\text { Tracker }\end{array}$ \\
exfdi1 & extensive margin & the number of industries & \\
exfdi2 & extensive margin & the number of enterprises & Transparency \\
cor & corruption & cor $=10-$ cpi & International \\
coc & square of corruption & square of cor & \\
Inmar & market size & $\ln ($ host country GDP) & World Bank \\
Inlab & labor cost & $\ln ($ host country per capita GDP) & database \\
ggdp & economic potential & GDP growth rate of host country & \\
open & trade openness & (export + import)/host country GDP & \\
res & resource endowment & total resource rent of the host country & \\
\hline
\end{tabular}

Table 2. Variables statistical description.

\begin{tabular}{ccccccc}
\hline Variable & Indicator & Mean & Std. & Min. & Max. & Obs \\
\hline \multicolumn{2}{c}{ dependent variables } & & & & & \\
Infdi & OFDI total scale & 7.26 & 1.102 & 4.61 & 9.56 & 238 \\
Inifdi & intensive margin & 6.20 & 0.715 & 4.61 & 8.58 & 238 \\
exfdil & extended margin (industries) & 2.54 & 1.400 & 1 & 7 & 238 \\
exfdi 2 & extended margin (enterprises) & 3.63 & 2.514 & 1 & 14 & 238 \\
\multicolumn{2}{c}{ independent variables } & & & & & \\
cor & corruption & 6.62 & 1.489 & 0.7 & 9.8 & 238 \\
coc ${ }^{2}$ & Squared corruption & 46.09 & 16.000 & 0.49 & 96.04 & 238 \\
& control variables & & & & & \\
Inmar & market size & 25.70 & 1.466 & 22.69 & 28.60 & 238 \\
Inlab & labor cost & 8.12 & 1.242 & 5.81 & 10.92 & 238 \\
ggdp & economic potential & 0.05 & 0.032 & -0.07 & 0.15 & 238 \\
open & trade openness & 0.73 & 0.544 & 0.18 & 2.81 & 238 \\
res & resource endowment & 12.76 & 13.262 & 0.00 & 60.12 & 238 \\
\hline
\end{tabular}

As can be seen from the data in the above Table 2, Chinese OFDI in some countries along the "Belt and Road" has not been diversified. Although the number of investment industries and the number of enterprises in some host countries have reached 7 and 14, the average of these two variables is only 1.400 and 2.514. From the perspective of extensive margin, it still shows the singularity of investment and is less resistant to external international investment risks. The average value of corruption index cor reached 6.62, while the world CPI average value was 4.23 in 2010-2017. According to the previous formula, the world corruption index cor average is 5.77, which is lower than the average corrup- 
tion index of 6.62 in this paper. This shows that Chinese OFDI enterprises are in the area with high corruption. Most of the countries along the way are in an external environment with a high level of corruption, which will inevitably lead to a bad market environment and may bring certain "frictional effects" to Chinese enterprises. In the sample data, the labor cost of the sample countries is 8.12 , while in China is 8.68 , which indicates that the relatively cheap labor cost of the countries along the "Belt and Road" may be the reason why Chinese enterprises choose to perform OFDI in these countries. As a result, these companies can maximize production profits. In terms of natural resource endowments, the sample country data accounted for an average of $12.76 \%$, which reflects to these countries have considerable natural resources. This is may the reason why China's resource-seeking companies choose to make OFDI in these host countries. From the perspective of economic growth rate, the average growth rate of countries along the "Belt and Road" is $5 \%$, far greater than the growth rate of the world economy. According to the report released by the United Nations in 2017, East Asia and South Asia account for nearly half of the world's economic growth. China alone contributes about one-third of global economic growth and $3 \%$ of the world's economic growth rate is the highest since 2011. This shows that the countries along the "Belt and Road" have certain development potential and will form a larger economic market in the future. It also proves that the "Belt and Road" is a correct initiative to achieve bilateral win-win situation.

\section{Basic Model Estimation}

From the above results, the lag term of the dependent variables of models (1)-(4) are significantly positive at the $1 \%$ level, which indicates that there is an agglomeration effect of Chinese enterprises in the OFDI along the "Belt and Road" countries. The previous OFDI will promote the next OFDI, because aggregation can increase the location advantage of multinational companies. A region that has already absorbed foreign-invested companies will have the advantage to absorb more new foreign investors to invest [20]. There is an agglomeration effect from both the marginal perspective and the binary marginal perspective.

The core independent variable cor is very significant in (1) and is negative, indicating that corruption in the countries along the "Belt and Road" has not "lubricated" the OFDI of Chinese enterprises, but hindered the entry of OFDI. Enterprises entering the host country will increase their investment costs due to imperfect market environment and the problems caused by rent-seeking and corruption, so it reduces the OFDI to the host country. From the intensive marginal perspective of the binary margin, the cor coefficient in (2) is negative, but not significant, indicating that the reduction of OFDI due to the increase of corruption level is not achieved by reducing the scale of OFDI. From the perspective of extensive margin, the cor coefficient in (3) is not significant, and the cor coefficient in (4) is significantly negative. The increased level of corruption in the host country has led Chinese companies to reluctant to set up factories in their countries, resulting in a decrease in the number of new busi- 
nesses in the host country and a decrease in OFDI flows. The impact of corruption in countries along the "Belt and Road" on the Chinese OFDI is mainly affecting the number of OFDI enterprises, not the average investment scale of OFDI.

In terms of control variables, the lnmar coefficient is significantly positive in (1) (3) (4), indicating that the larger the market size of the host country, the more it can promote the entry of Chinese OFDI. It is also conducive to promoting the diversification of China's investment. The labor cost lnlab coefficient is significantly negative in (4), indicating that the cheap labor of the host country is the reason for attracting Chinese enterprises to invest in the host country. The economic growth potential $g g d p$ coefficient is significantly positive in (2), which means that the greater the economic potential can attract much bigger average investment scale. The trade openness open coefficient is significantly negative in (1) (2) (4), indicating that the increase in trade openness of countries along the "Belt and Road" does not actually promote the scale of OFDI, but rather reduces the number of Chinese enterprises. The relationship between the host country's trade and the introduction of foreign investment may be an alternative, which is in line with Mundell's mutual substitution model. The res coefficient is not significant, so the natural resource elements of the host country are not a factor in attracting OFDI.

The last three rows in the Table 3 are the tests set for the system GMM model. The results of the Sargan statistic for models (1)-(4) are all bigger than 0.1, indicating that the selected tool variables are valid. From the results of $\operatorname{AR}(1)$ and $\mathrm{AR}(2)$, the residual terms of models (1)-(4) have first-order autocorrelation and second-order autocorrelation. Therefore, the setting of the system GMM model is effective.

Table 3. Basic model estimation.

\begin{tabular}{ccccc}
\hline & $(1)$ & $(2)$ & $(3)$ & $(4)$ \\
\hline Infdi & Inifdi & exfdil & exfdi2 \\
\hline \multirow{2}{*}{ L.Infdi } & $0.186^{* * *}$ & & & \\
& $(0.0589)$ & & &
\end{tabular}

$0.109^{* * *}$
$(0.0184)$

L.exfdi1

L.exfdi2

cor

Inmar $-0.420^{\text {***}}$

(0.105)

$0.489^{* *}$
$0.0824^{*}$

(0.0426)

$\begin{array}{cc} & 0.245^{* * *} \\ & (0.0418) \\ 0.0150 & -0.295^{* *} \\ (0.0917) & (0.171) \\ 0.729^{*} & 0.868^{* *}\end{array}$




\begin{tabular}{|c|c|c|c|c|}
\hline \multicolumn{5}{|l|}{ Continued } \\
\hline & $(0.207)$ & $(0.0518)$ & $(0.395)$ & $(0.269)$ \\
\hline \multirow[t]{2}{*}{ Inlab } & 0.0585 & 0.222 & -0.254 & $-1.215^{\star * *}$ \\
\hline & $(0.267)$ & $(0.114)$ & $(0.443)$ & $(0.453)$ \\
\hline \multirow[t]{2}{*}{$g g d p$} & 0.0131 & $4.568^{\star * *}$ & 1.538 & 6.047 \\
\hline & $(2.457)$ & $(1.156)$ & $(2.757)$ & $(4.732)$ \\
\hline \multirow{2}{*}{ open } & $-1.803^{* * *}$ & $-0.485^{\star * *}$ & -1.013 & $-1.256^{\star *}$ \\
\hline & $(0.216)$ & $(0.139)$ & $(0.647)$ & $(0.526)$ \\
\hline \multirow[t]{2}{*}{ res } & -0.00217 & -0.000431 & -0.0263 & -0.0409 \\
\hline & $(0.00616)$ & $(0.00401)$ & $(0.0136)$ & $(0.0229)$ \\
\hline \multirow[t]{2}{*}{ cons } & -2.971 & $6.887^{* * *}$ & $-13.43^{\star}$ & -5.869 \\
\hline & $(5.571)$ & (1.858) & (7.194) & $(5.127)$ \\
\hline$N$ & 200 & 200 & 200 & 200 \\
\hline$A R(1)$ & 0.0001 & 0.0034 & 0.0017 & 0.0001 \\
\hline$A R(2)$ & 0.5364 & 0.6021 & 0.1006 & 0.5993 \\
\hline Sargan & 0.9998 & 0.9997 & 0.9981 & 0.9824 \\
\hline
\end{tabular}

Standard errors in parentheses, ${ }^{*} \mathrm{p}<0.1,{ }^{* *} \mathrm{p}<0.05,{ }^{* * *} \mathrm{p}<0.01$.

\section{Estimation of Introducing cor $^{2}$}

In order to further test whether corruption in the host country is nonlinear with the Chinese OFDI, we introduces the square of the corruption in the models (1)-(4) respectively. The regression results are shown in Table 4. First, the lag term of the dependent variables of models (5)-(8) is significantly positive, indicating the existence of aggregation effects. This result is the same as in Table 3.

The coefficient cor is the same as in Table 3 , which are significantly negative in terms of the total investment scale and the number of enterprises, but not significant in the average investment scale and the number of investment industries. Another core independent variable $c o r^{2}$ is significantly positive in models (5) and (8). From the perspective of OFDI total scale and extensive margin, combined with the coefficient cor, there is a nonlinear " $U$ " relationship between corruption and OFDI. Within a certain level of corruption, corruption in countries along the "Belt and Road" has a "frictional effect" on the OFDI total scale and the number of invested enterprises. However, when the level of corruption increases beyond a certain threshold, the level of corruption will transform into "Lubrication effect" for Chinese OFDI. This is because in some host countries with low levels of corruption, corruption will inhibit Chinese OFDI inflows by increasing the uncertainty of the investment environment and increasing the operating costs of investment activities. In some host countries with high levels of corruption (exceed the threshold), their governance environment is often inferior, such as the government's intervention and supervision of foreign-funded enterprises, the inefficient operation of government agencies, and the imperfect legal system. At this time, the host country cannot create an institutional environment for investors to be fair, efficient and able to effectively protect property 
Table 4. Estimation of introducing cor $^{2}$.

\begin{tabular}{|c|c|c|c|c|}
\hline & (5) & (6) & (7) & (8) \\
\hline & $\operatorname{Infdi}$ & Inifdi & exfdil & exfdi2 \\
\hline \multirow[t]{2}{*}{ L.Infdi } & $0.181^{\star * \star}$ & & & \\
\hline & $(0.0618)$ & & & \\
\hline \multirow[t]{2}{*}{ L.Inifdi } & & $0.0675^{\star \star}$ & & \\
\hline & & $(0.0300)$ & & \\
\hline \multirow[t]{2}{*}{ L.exfdi 1} & & & $0.0805^{\star *}$ & \\
\hline & & & $(0.0337)$ & \\
\hline \multirow[t]{2}{*}{ L.exfdi2 } & & & & $0.243^{* * *}$ \\
\hline & & & & $(0.0364)$ \\
\hline \multirow[t]{2}{*}{ cor } & $-1.120^{* * *}$ & -0.398 & -0.358 & $-1.870^{\star *}$ \\
\hline & $(0.338)$ & $(0.372)$ & $(0.530)$ & $(0.806)$ \\
\hline \multirow[t]{2}{*}{$\operatorname{coc}^{2}$} & $0.0649^{* * *}$ & 0.0193 & 0.0217 & $0.136^{* *}$ \\
\hline & $(0.0236)$ & $(0.0256)$ & $(0.0374)$ & $(0.0586)$ \\
\hline \multirow[t]{2}{*}{ Inmar } & $0.471^{\star *}$ & -0.0602 & 0.0377 & $1.025^{\star * *}$ \\
\hline & $(0.230)$ & $(0.143)$ & $(0.391)$ & $(0.282)$ \\
\hline \multirow[t]{2}{*}{ Inlab } & 0.541 & 0.0986 & 0.497 & $-1.115^{\star *}$ \\
\hline & $(0.477)$ & $(0.253)$ & $(0.432)$ & $(0.540)$ \\
\hline \multirow[t]{2}{*}{$g g d p$} & 2.135 & $4.802^{\star \star \star}$ & 1.414 & 4.118 \\
\hline & (2.538) & $(1.161)$ & $(2.531)$ & $(4.961)$ \\
\hline \multirow[t]{2}{*}{ open } & $-2.009^{* * *}$ & $-0.507^{\star \star}$ & $-1.448^{\star}$ & $-1.915^{*}$ \\
\hline & $(0.193)$ & $(0.219)$ & $(0.798)$ & $(1.054)$ \\
\hline \multirow[t]{2}{*}{ res } & -0.00598 & 0.00355 & -0.0245 & -0.0443 \\
\hline & $(0.00694)$ & $(0.00650)$ & $(0.0151)$ & $(0.0290)$ \\
\hline \multirow[t]{2}{*}{ cons } & -4.400 & $8.803^{* * *}$ & 0.191 & -6.013 \\
\hline & (7.063) & $(2.950)$ & (7.994) & $(6.754)$ \\
\hline$N$ & 200 & 200 & 200 & 200 \\
\hline$A R(1)$ & 0.0001 & 0.0028 & 0.0016 & 0.0000 \\
\hline$A R(2)$ & 0.4476 & 0.6432 & 0.1004 & 0.6315 \\
\hline Sargan & 0.9998 & 1.0000 & 1.0000 & 0.9857 \\
\hline
\end{tabular}

Standard errors in parentheses, ${ }^{*} \mathrm{p}<0.1,{ }^{* *} \mathrm{p}<0.05,{ }^{* * *} \mathrm{p}<0.01$.

rights. Corruption is a sub-optimal choice for effective resource allocation. It can not only make up for the shortcomings of the host country system, but also help investors to bypass the various investment barriers of the host country as soon as possible. It can reduce the institutional friction with the host government and facilitate the entry of Chinese OFDI. From the intensive perspective, the level of corruption in the host country does not significantly affect the average investment by Chinese enterprises, which is consistent with the results in Table 3. These results show that the impact of corruption on Chinese OFDI structure is 
reflected in the number of invested enterprises.

The coefficients of the control variables are similar to the results of Table 3. The Sargan statistic and residual term autocorrelation test results $A R(1)$ and $\mathrm{AR}(2)$ are also the same as those in Table 3, indicating the design of the system GMM estimation based on the model (5)-(8) after introducing the $c o r^{2}$ still valid.

\section{Robustness Test}

In order to verify the robustness of the above regression results, we use the method of replacing the core independent variables for robustness test. We use the cci (corruption control index) in the World Bank's Worldwide Governance Indicators (WGI) database to replace the original variable cor for robustness testing. The $c c i$ index ranges from -2.5 (most corrupt) to 2.5 (most clean), so we reversed the value of $c c i$. Defining $c o c=2.5-c c i$. It means the bigger the value of $c o c$, the more serious the corruption. The regression results of the robustness test are as follows in Table 5.

From the above regression results, it can be seen that although the independent variables have decreased significantly, they are still significant at the significant level of $10 \%$. Direction of the coefficient are consistent with the original model results. The corruption and the Chinese OFDI are "U" type relationship. Corruption only affects the extensive margin of Chinese OFDI rather than the intensive margin, which is consistent with the empirical results in Table 3 and Table 4. Control variables are in the model but not reported.

\section{Conclusions and Suggestion}

This paper uses China's China Global Investment Tracker to analyze the OFDI panel data of 31 countries along the "Belt and Road" countries in 2010-2017. We use the systematic GMM estimation method to study the relationship between the level of corruption and OFDI from a binary marginal perspective. The results of the system GMM estimation show that from the perspective of the OFDI total scale, there is a " $U$ " relationship between corruption and OFDI. From the perspective of intensive margin, the relationship between host country corruption and the average amount foreign investment of Chinese enterprises is not significant. From the perspective of extensive margin, corruption and the number of enterprises setting up factories in the host country also show U-shaped

Table 5. Robustness test.

\begin{tabular}{|c|c|c|c|c|c|c|c|c|}
\hline & $\ln f d i$ & $\operatorname{lnfdi}$ & Inifdi & Inifdi & exfdil & exfdi1 & exfdi2 & exfdi2 \\
\hline \multirow[t]{2}{*}{$\operatorname{coc}$} & $-0.269^{* * *}$ & $-1.201^{\star * *}$ & 0.0531 & -3.868 & -0.236 & -4.891 & $-0.382^{\star \star}$ & $-6.503^{*}$ \\
\hline & $(0.224)$ & $(1.364)$ & $(0.263)$ & $(1.853)$ & $(0.242)$ & $(1.712)$ & $(0.565)$ & $(3.652)$ \\
\hline \multirow[t]{2}{*}{$\operatorname{coc}^{2}$} & & $0.214^{* *}$ & & 0.675 & & 0.833 & & $1.123^{*}$ \\
\hline & & $(0.219)$ & & $(0.308)$ & & $(0.289)$ & & $(0.664)$ \\
\hline
\end{tabular}

Standard errors in parentheses ${ }^{*} \mathrm{p}<0.05,{ }^{* *} \mathrm{p}<0.01,{ }^{* * *} \mathrm{p}<0.001$. 
relationship, but the relationship with the number of investment industries is not significant.

With the introduction of the national "Belt and Road Initiative" initiative, more and more enterprises choose to "go global". Many Chinese enterprises investing in developing countries is gradually increasing. Corruption has a certain "frictional effect" on Chinese enterprises, such as raising the uncertainty of the investment environment, increasing the risk of property rights being invaded and increasing operating costs. However, due to the pursuit of the market or the pursuit of cheap labor, Chinese enterprises still choose to flow to some countries with high levels of corruption. They enjoy the "lubricating effect". The "lubricating effect" of corruption is more likely to play a role in the institutional environment in which the host country's incentives are distorted, or the result of suboptimal choices of investors when the host country's institutional arrangements are flawed. As the host country's economic system and political system continue to develop and improve, this "lubrication effect" will be difficult to sustain in the long run. We believe that the government should further strengthen the public services of foreign direct investment and improve the information service system for foreign investment cooperation. It can strengthen the construction of the "going out" public service platform. At the same time, we need national environmental guidance for companies to conduct foreign investment cooperation. Let Chinese enterprises have a more comprehensive and detailed understanding of the host country when they "go out". Giving full play to the advantages of Chinese enterprises and choosing the host country that is suitable for them to carry out OFDI, so that China and the host countries can share the development opportunities brought about by the "Belt and Road Initiative" and achieve a win-win situation.

\section{Conflicts of Interest}

The author declares no conflicts of interest regarding the publication of this paper.

\section{References}

[1] Habib, M. and Zurawicki, L. (2002) Corruption and Foreign Direct Investment. Journal of International Business Studies, 33, 291-307. https://doi.org/10.1057/palgrave.jibs.8491017

[2] Blonigen, B.A. (2005) A Review of the Empirical Literature on FDI Determinants. Atlantic Economic Journal, 33, 383-403. https://doi.org/10.1007/s11293-005-2868-9

[3] Demirbag, M., Glaister, K.W. and Tatoglu, E. (2007) Institutional and Transaction Cost Influences on MNEs' Ownership Strategies of Their Affiliates: Evidence from an Emerging Market. Journal of World Business, 42, 418-434. https://doi.org/10.1016/j.jwb.2007.06.004

[4] Bhaumik, S.K., Driffield, N. and Pal, S. (2010) Does Ownership Structure of Emerging-Market Firms Affect Their Outward FDI? The Case of the Indian Automotive and Pharmaceutical Sectors. Journal of International Business Studies, 41 437-450. https://doi.org/10.1057/jibs.2009.52 
[5] Duanmu, J.L. (2011) The Effect of Corruption Distance and Market Orientation on the Ownership Choice of MNEs: Evidence from China. Journal of International Management, 17, 162-174. https://doi.org/10.1016/j.intman.2011.01.003

[6] Das, A. and Parry, M. (2011) Greasing or Sanding? GMM Estimation of the Corruption-Investment Relationship. International Journal of Environmental Research, 2, 95-108.

[7] Egger, P. and Winner, H. (2005) Evidence on Corruption as an Incentive for Foreign Direct Investment. European Journal of Political Economy, 21, 932-952. https://doi.org/10.1016/j.ejpoleco.2005.01.002

[8] Egger, P. and Winner, H. (2006) How Corruption Influences Foreign Direct Investment: A Panel Data Study. Economic Development and Cultural Change, 54, 459-486. https://doi.org/10.1086/497010

[9] Buckley, P.J., Clegg, L.J., Cross, A.R., Liu, X., Voss, H. and Zhang, P. (2007) The Determinants of Chinese Outward Foreign Direct Investment. Journal of International Business Studies, 38, 499-518. https://doi.org/10.1057/palgrave.jibs.8400277

[10] Kolstad, I. and Wiig, A. (2009) Is Transparency the Key to Reducing Corruption in Resource-Rich Countries? World Development, 37, 521-532. https://doi.org/10.1016/j.worlddev.2008.07.002

[11] Cheung, Y.W., de Haan, J., Qian, X.W., et al. (2011) China's Outward Direct Investment in Africa. Working Paper, Hong Kong Institute for Monetary Research, Hong Kong.

[12] Jiang, G. and Jiang, D. (2012) Chinese Investment in Developing Countries-Is the Host Country System Important? Management World, 11, 45-56.

[13] Fung, K.C. and Garcia-Herrero, A. (2012) Foreign Direct Investment Outflows from China and India. China Economic Policy Review, 1, Article ID: 1250003. https://doi.org/10.1142/S1793969012500033

[14] Straub, S. (2005) Informal Sector: The Credit Market Channel. Journal of Development Economics, 78, 299-321. https://doi.org/10.1016/j.jdeveco.2004.09.005

[15] Méon, P.G. and Weill, L. (2008) Is Corruption an Efficient Grease? Bank of Finland. Institute for Economies in Transition, BOFIT Discussion Papers, 20. https://doi.org/10.2139/ssrn.1304596

[16] Craigwell, R. and Wright, A. (2011) Foreign Direct Investment and Corruption in Developing Economies: Evidence from Linear and Non-Linear Panel Granger Causality Tests. Economics Bulletin, 31, 2272-2283.

[17] Brada, J.C., Drabek, Z. and Perez, M.F. (2012) The Effect of Home-Country and Host-Country Corruption on Foreign Direct Investment. Review of Development Economics, 16, 640-663. https://doi.org/10.1111/rode.12009

[18] Hu, B., Deng, F. and Zhang, M. (2013) Influence of Host Country Corruption on China's Outward Direct investment: An Empirical Analysis Based on Cross-Country Panel Data. Journal of International Trade, 10.

[19] Yang, L., Liu, X. and Zhang, J. (2016) How Do Bilateral Political Relations Affect Outward Foreign Direct Investment-Based on a Perspective of Binary Margin and Investment Failure. China Industry Economy, 11, 56-72.

[20] Dunning, J.H. and Lundan, S.M. (2008) Theories of Foreign Direct Investment. In: Dunning, J.H. and Lundan, S.M., Eds., Multinational Enterprises and the Global Economy, Edward Elgar Publishing Limited, Cheltenham, 79-115. 